\title{
Pengujian Struktur Sepatu Kuda Bahan Komposit Polymeric Foam Berpenguat Fiberglass Menggunakan Uji Impak Jatuh Bebas
}

\author{
Mawardi $^{1 *}$, Bustami Syam², Maraghi Muttaqin ${ }^{3}$ \\ ${ }^{1,}$ Staf Pengajar Program Studi Teknik Mesin Fakultas Teknik Universitas Al-Azhar Medan \\ Email:*mawardi.ipc@gmail.com
}

\begin{abstract}
This study aims to determine the mechanical structure of polymeric foam reinforced with fiberglass horseshoes. Observations are focused on the average maximum impact force and the average maximum impact stress obtained from the free fall impact test. Testing the free fall impact structure with an impactor weight of $10 \mathrm{~kg}$ on five horseshoe test specimens $1,2,3,4$ and 5 with an impact distance of 2.5 meters, 2 meters, 1.5 meters, 1 meter and 0.5 meters, the results are horse shoe test specimens does not experience cracks / broken. The results obtained are in the form of the highest stress on the 1A test specimen with a stress value of $0.154 \mathrm{MPa}$ and the maximum force found in the 1A test specimen of $874.95 \mathrm{~N}$. with an impactor weight of $12.5 \mathrm{~kg}$ the test specimen cracks / breaks at a height of $3 \mathrm{~m}$ and $2.5 \mathrm{~m}$, resulting in the highest impact stress value in sample $6 B$ of $0.21 \mathrm{MPa}$ and a force of $1185.5 \mathrm{~N}$. then the force and stress will be higher but the level of damage will also be greater.
\end{abstract}

Keywords: Polymeric foam, Fiberglass, five compositions, test specimens, structural testing.

\section{PENDAHULUAN}

Kuda merupakan jenis hewan ternak yang dimanfaatkan oleh manusia untuk aktivitas. Karakteristik kuda diantaranya memiliki tenaga yang sangat kuat, gagah, berani juga merupakan hewan yang bergerak cepat [1]. Umumnya sepatu kuda terbuat dari bahan konvensional baja dan aluminium. Permasalahnnya adalah tingkat kerusakan dan keausan bahan baja ini cukup tinggi sehingga pemakaiannya relatif cepat [2]. Berangkat dari hal tersebut peneliti merencanakan membuat sepatu kuda dari bahan komposit polymeric foam dengan penguat fiberglass. Bahwa penelitian sepatu kuda ini merupakan lanjutan dari penelitian sebelumnya yaitu mengambil hasil terbaik uji karakteristik tekan statik dan uji tarik terhadap lima komposisi bahan A, B, C, D dan E. Dimana komposisi terbaik terdapat pada komposisi $\mathrm{C}$ dengan persentasi resin 55\%, blowing agent $30 \%$, katalis $5 \%$ dan fiberglass 10\% [3]. Bahan komposit adalah bahan yang dibuat dari dua atau lebih bahan penyusun dengan sifat fisik (kimia) yang berbeda, bila dikombinasikan akan menghasilkan bahan dengan karakteristik dan struktur yang berbeda. Komposit berpenguat serat banyak diaplikasikan pada alat-alat yang membutuhkan material yang mempunyai dua perpaduan sifat dasar, yaitu kuat dan ringan [4]. Serat alam yang direaksikan dengan matriks polyester resin tak jenuh seri 157 BTN-EX dapat meningkatkan kestabilan dimensi dan kekakuannya [5]. Sepatu kuda yang umum digunakan adalah baja carbon steel standard American Iron and Steel Institute (AISI 1016) [6].

\section{Tinjauan Pustaka}

Henry Burden di Amerika Serikat mematenkan mesin pembuatan sepatu kuda pertama tahun 1835 M. Mesin ini bisa menghasilkan maksimal 60 buah sepatu kuda per jam. Meskipun tidak diketahui siapa yang menemukan sepatu kuda pertama sekali, namun beberapa tahun kemudian pada tahun 1861 M, J.B. Kendall mematenkan sepatu kuda bahan komposit (composite) pertama. Beberapa tahun kemudian, Oscar E. Brown menemukan tapal kuda ganda pada tahun 1892 M [2,7]. Bahan komposit polymeric foam terdiri dari polyester resin tak jenuh dan blowing agent. Blowing agent yang digunakan dalam penelitian ini adalah polyol dan isocyanate. Resin merupakan polimer 
kondensat yang terbentuk dari reaksi polyol yang merupakan organik gabungan multi alkohol (hidroksi) dengan polycarboxylic yang mengandung ikatan ganda. Jenis polyol yang digunakan adalah ethylene glycol [8].

Gaya reaksi $F$ posisinya sangat menentukan nilai a dan nilai dari momen $\mathrm{F}_{\mathrm{a}}$. Untuk mencari posisi dari $\mathrm{F}$ kita mesti mengetahui analisa gaya yang dialami kuku kuda ketika berlari (gallop) dapat dilihat pada gambar 1 momen pada kaki kuda saat berdiri.

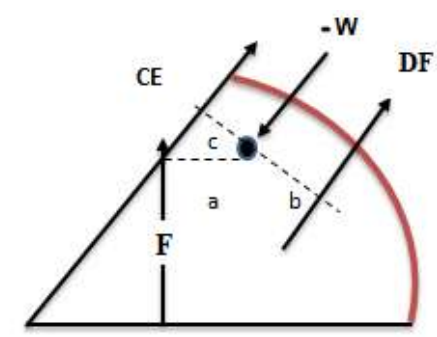

Gambar 1. Momen pada sepatu kuda

Kekuatan F, CE, dan DF adalah positif dan berlawanan arah dengan vektor bobot tubuh -W. Dinding kuku biasanya sejajar dengan vektor gaya $\mathrm{W}$ dan $-\mathrm{W}$, kuku dan dinding kuku akan menjadi yang terkuat ketika kuku kuda sesuai dengan gaya yang dihasilkan [9]. Beban maksimum yang dialami posisi kuda diam adalah secara rinci diperlihatkan pada Figure 2.

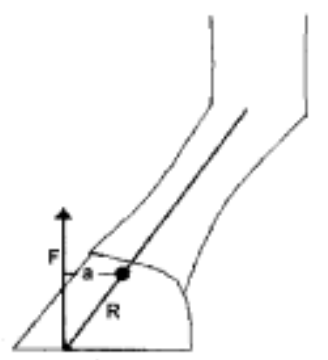

Gambar 2. Posisi resultan $\mathrm{R}$

Posisi dari R normalnya paralel dengan tanduk (horn) dari dinding kuku kuda oleh kuku kuda adalah 2,4 kali berat kuda itu sendiri [10]. Persamaannya adalah:

$\mathrm{F}=\mathrm{m} \cdot \mathrm{g} \cdot 2,4(\mathrm{kN})$

Benda jatuh tanpa kecepatan awal $(\mathrm{Vo}=$ nol). Semakin ke bawah gerak benda semakin cepat. Percepatan yang dialami oleh setiap benda jatuh bebas selalu sama, yakni sama dengan percepatan gravitasi bumi $(\mathrm{a}=\mathrm{g})$ nilainya sebesar $\mathrm{g}=9,8 \mathrm{~m} / \mathrm{s}^{2}$. Jatuhnya benda tersebut memiliki harga kecepatan yang sama setiap detiknya. Harga yang sama percepatan benda akan berkurang jika ditembakkan keatas [11].

\section{METODE}

Model sepatu kuda yang direncanakan juga harus memiliki fungsi dan sifat yang ergonomik yaitu nyaman dipakai,. Estetika yaitu memenuhi syarat keindahan dipandang secara visual mata, Safety, sangat aman tidak berbahaya secara kesehatan. Stability, tidak membuat cedera karena ketidak stabilan (oleng). Simpel, berkaitan dengan waktu yang dibutuhkan memasang sepatu kuda tidak perlu lama. Karakteristik mekanik yang diinginkan gaya dan tegangan melalui uji impak jatuh bebas pada variabel komposisi A, B, C, D dan E. Komposisi bahan penyusun pembuatan spesimen sepatu kuda diperlihatkan pada tabel 1, dimana komposisi terbaik dari pengujian Tekan statik dan uji tarik terdapat pada komposisi C. 
Tabel 1. Komposisi Bahan Penyusun sepatu kuda

\begin{tabular}{lccccc}
\hline \multicolumn{1}{c}{ Bahan } & Komposisi & Komposisi & Komposisi & Komposisi & Komposisi \\
Penyusun & $\mathrm{A}(\%)$ & $\mathrm{B}(\%)$ & $\mathrm{C}(\%)$ & $\mathrm{D}(\%)$ & E $(\%)$ \\
\hline Resin & 65 & 60 & 55 & 50 & 45 \\
Blowing Agent & 20 & 25 & 30 & 35 & 40 \\
Katalis & 5 & 5 & 5 & 5 & 5 \\
Fiberglass & 10 & 10 & 10 & 10 & 10 \\
\hline
\end{tabular}

\section{Tempat, Waktu, Alat Bantu dan Bahan}

Tempat penelitian ini di Pusat Riset Impak dan Keretakan Unit I, Dept. Teknik Mesin Universitas Sumatera Utara. Waktu pelaksanaan penelitian dilakukan selama 10 bulan, terhitung mulai Januari 2019 - Desember 2019. Alat bantu yang utama sigmat dan timbangan digital $5 \mathrm{~kg}$. Bahan yang digunakan fiberglass, resin, katalis, blowing agent (polyol dan isocyanate).

\section{Pengujian Struktur Impak Jatuh Bebas}

Pengujian struktur bertujuan untuk menghasilkan respon mekanik material dalam hal ini adalah pengujian impak jatuh bebas.

\section{Parameter}

Parameter uji pengujian impak jatuh bebas seperti jarak. Jarak ketinggian impaktor 2,5m, $2 \mathrm{~m}, 1,5 \mathrm{~m}, 1 \mathrm{~m}$ dan $0.5 \mathrm{~m}$ sebagai variabel bebas dan berat impaktor $10 \mathrm{~kg}$ sebagai variabel tetap

\section{Spesimen pengujian impak jatuh bebas}

Contoh spesimen uji sepatu kuda uji impak jatuh bebas diperlihatkan pada gambar 3 .

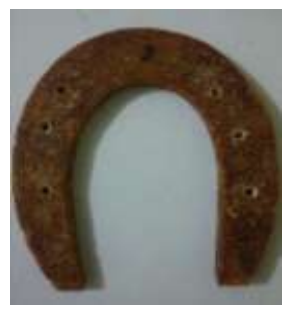

Gambar 3. Contoh spesimen uji impak jatuh bebas

\section{Cetakan spesimen uji impak jatuh bebas}

Cetakan spesimen uji impak jatuh bebas terbuat dari steel model three pcs body, yaitu bagian penutup atas, penutup bawah dan body tengah untuk bahan polymeric foam, ukurannya adalah panjang $115 \times$ lebar $95 \times$ tebal $10 \mathrm{~mm}$. Cetakannya diperlihatkan pada gambar 4 berikut.

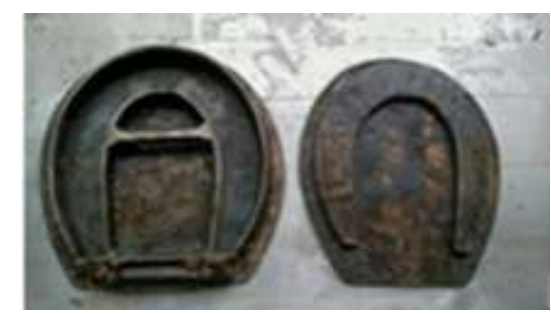

Gambar 4. Cetakan spesimen

\section{Set-up alat pengujian impak jatuh bebas}

Anvil test rig dipasang pada posisinya tempat jatuhnya impaktor. Tombol start pada software DAQ for Helmet Impact Testing dan sensor proximity pada posisi On. Spesimen uji sudah 


\section{Jurnal Rekayasa Material, Manufaktur dan Energi}

terpasang pada impaktor dan jarak ketinggian sudah di set sesuai kebutuhan. Maka spesimen siap di uji. Simpan data hasil uji ke dalam file berformat Excell.

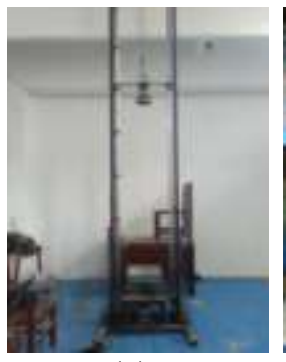

(a)

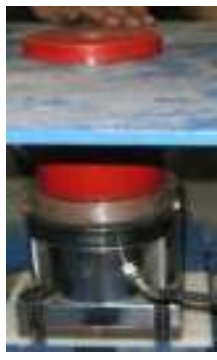

(b)

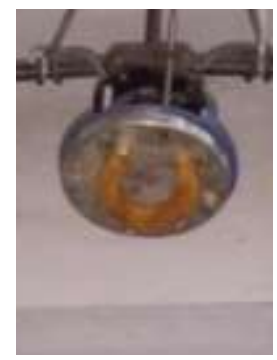

(c)

Gambar 5. (a) alat uji Impak jatuh Bebas (b) Load cell terpasang (c) impaktor

\section{Spesimen Uji, Jarak dan Beban Impaktor}

Variasi ketinggian sebagai variabel bebas dan variasi berat impaktor $10 \mathrm{~kg}$ dan $12.5 \mathrm{~kg}$ sebagai variabel tetap terhadap 21 spesimen uji dan spesifiksinya diperlihatkan pada tabel 2.

Tabel 2 Variasi model sepatu kuda

\begin{tabular}{cccc}
\hline No & $\begin{array}{c}\text { Spesimen Uji } \\
\text { Sepatu Kuda }\end{array}$ & Ketinggian Impaktor $(\mathrm{m})$ & Berat Impaktor $(\mathrm{kg})$ \\
\hline 1 & 1A, 1B dan 1C & 2,5 & 10 \\
2 & $2 \mathrm{~A}$, 2B dan 2C & 2 & 10 \\
3 & 3A, 3B dan 3C & 1.5 & 10 \\
4 & 4A, 4B dan 4C & 1 & 10 \\
5 & $5 \mathrm{~A}$, 5B dan 5C & 0.5 & 10 \\
6 & 6A, 6B dan 6C & 3 & 12,5 \\
7 & 7A, 7B dan 7C & 2,5 & 12,5 \\
\hline
\end{tabular}

\section{HASIL DAN PEMBAHASAN}

1. Pengujian impak ini menggunakan metode pengujian impak jatuh bebas dilakukan terhadap spesimen sepatu kuda. Jenis anvil yang dipakai adalah plat datar. Dalam pengujian ini variabel yang diamati pertama jarak pengimpakan sampel sepatu kuda terhadap anvil. Kedua distribusi tegangan yang terjadi pada permukaan sampel sepatu kuda setelah dikenai beban impak. Ketiga adalah besar kekuatan material spesimen sepatu kuda terhadap beban impak jatuh bebas yang diberikan. spesimen uji sepatu kuda dipasang pada impaktor bersamaan dengan beban $10 \mathrm{~kg}$ dan $12.5 \mathrm{~kg}$ pada ketinggian yang diinginkan dan dijatuhkan ke permukaan anvil sehingga benda kerja mengalami respon tegangan dan gaya yang bekerjan dan memiliki kemampuan yang dibutuhkan sepatu kuda.

2. Hasil Pengujian spesimen $1 \mathrm{~A}, 1 \mathrm{~B}$ dan $1 \mathrm{C}$ ketinggian 2.5 meter Beban $10 \mathrm{Kg}$. 


\section{Jurnal Rekayasa Material, Manufaktur dan Energi}

Berikut ini adalah spesimen uji sebelum dan sesudah pengujian impak jatuh bebas.

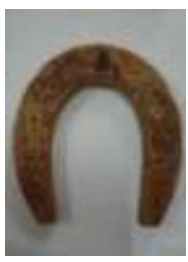

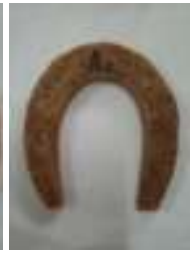

(a)

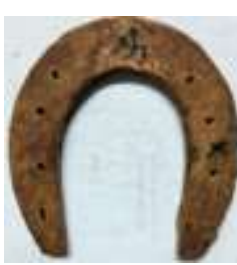

(b)

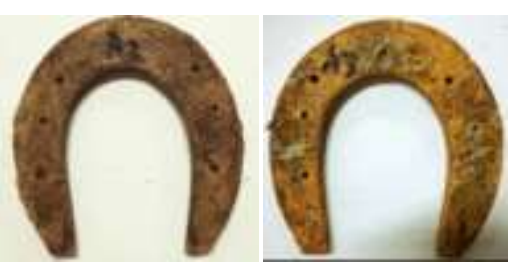

Gambar 6. Spesimen 1 (a) sebelum diuji (b) Setelah Diuji

Ketinggian impaktor 2,5 meter dijatuhkan beban $10 \mathrm{~kg}$ spesimen 1A, 1B dan 1C tidak mengalami keretakan. Hasil datanya diperlihatkan pada grafik gambar 7 dibawah ini.

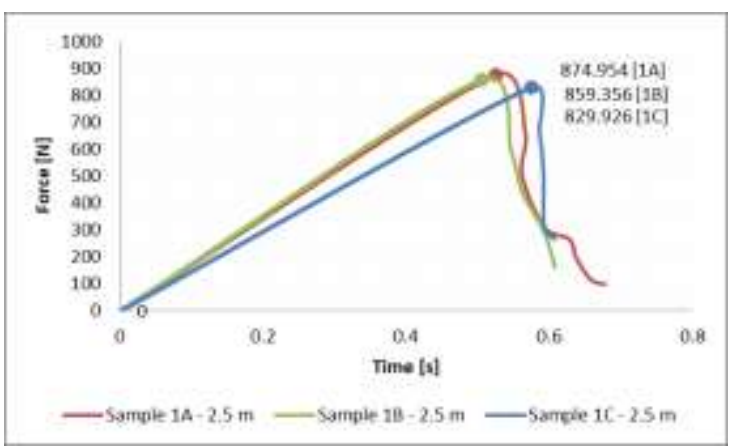

(a)

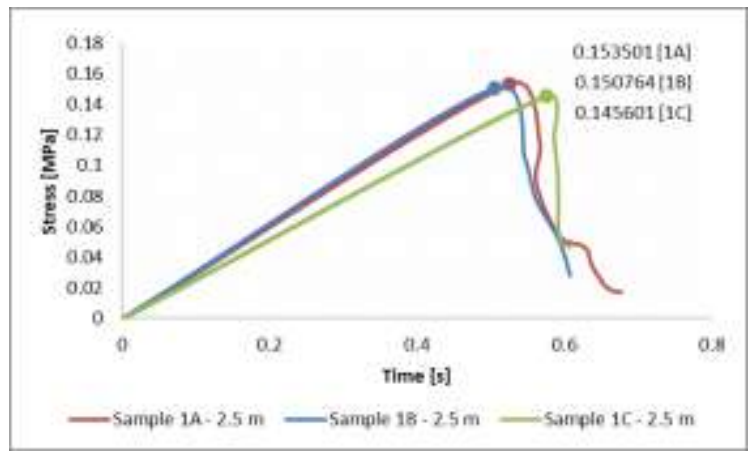

(b)

Gambar 7. Grafik Spesimen1A, 1B dan 1C (a) Gaya Vs Waktu (b) Tegangan Vs Waktu

Hasil yang diperoleh dimana gaya maksimum dan tegangan maksimum terdapat pada Spesimen 1A, nilainya dapat kita lihat pada tabel 3 berikut.

Tabel 3. Data uji impak jatuh bebas spesimen 1 sepatu kuda ketinggian 2.5 meter

\begin{tabular}{cccccc}
\hline No & $\begin{array}{c}\text { Ketinggian } \\
(\mathrm{m})\end{array}$ & Spesimen & $\begin{array}{c}\text { Gaya Maksimum } \\
(\mathrm{N})\end{array}$ & $\begin{array}{c}\text { Tegangan Maksimum } \\
(\mathrm{MPa})\end{array}$ & Kondisi \\
\hline 1 & 2.5 & $1 \mathrm{~A}$ & 874.954 & 0.153 & Cacat \\
2 & 2.5 & $1 \mathrm{~B}$ & 859.356 & 0.150 & Cacat \\
3 & 2.5 & $1 \mathrm{C}$ & 829.926 & 0.146 & Cacat \\
\hline \multicolumn{2}{c}{ Rata-rata } & 854.745 & 0.150 & \\
\hline
\end{tabular}

3. Hasil pengujian impak jatuh bebas spesimen 2 ketinggian 2 meter Beban $10 \mathrm{Kg}$

Spesimen uji 2 sebelum dan sesudah pengujian diperlihatkan pada gambar berikut ini 


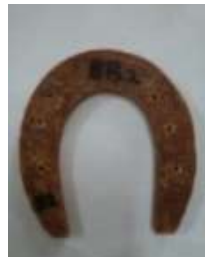

(a)

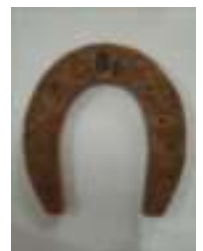

Gambar 8. Spesimen 2 (a) Sebelum diuji (b) Setelah diuji

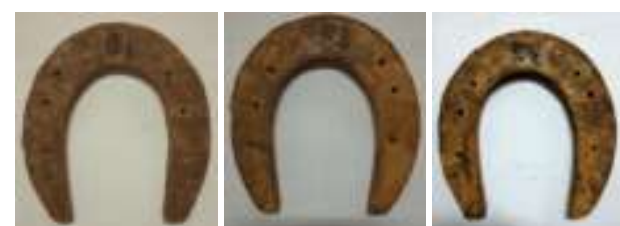

(b)

Spesimen uji dijatuhkan dari ketinggian 2 meter bersama beban $10 \mathrm{~kg}$, tidak mengalami kerusakan. Nilai tegangan tertinggi dari dampak yang dihasilkan oleh gaya tertinggi terdapat pada spesimen 2C dengan nilai gaya $809.79 \mathrm{~N}$. Detil nilai dapat kita lihat pada gambar dan tabel berikut ini.

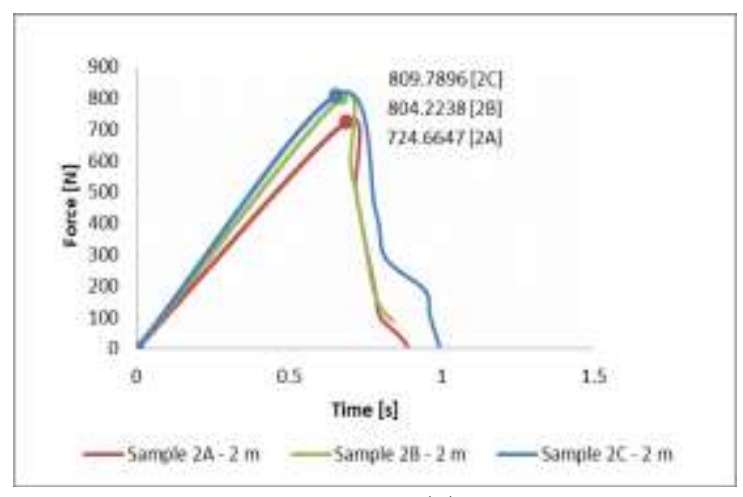

(a)

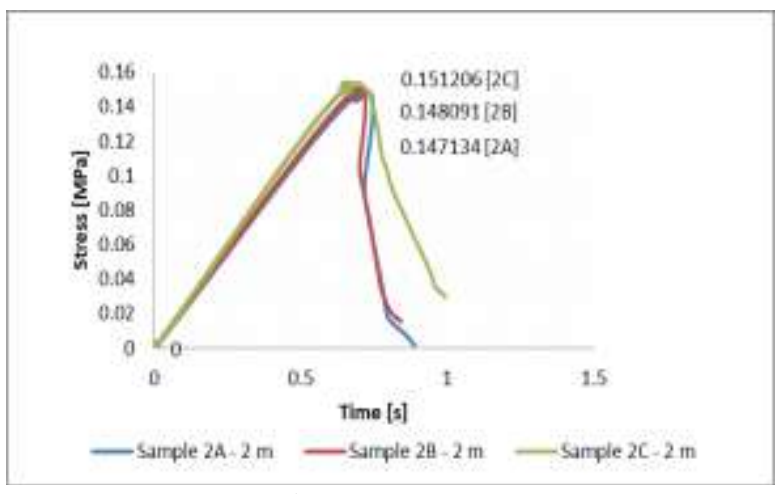

(b)

Gambar 9. Grafik Spesimen 2 (a) Gaya Vs Waktu (b) Tegangan Vs Waktu

Tabel 4. Data uji impak spesimen 2 sepatu kuda ketinggian 2 meter

\begin{tabular}{cccccc}
\hline No & $\begin{array}{c}\text { Ketinggian } \\
(\mathrm{m})\end{array}$ & Spesimen & $\begin{array}{c}\text { Gaya Maksimum } \\
(\mathrm{N})\end{array}$ & $\begin{array}{c}\text { Tegangan Maksimum } \\
(\mathrm{MPa})\end{array}$ & Kondisi \\
\hline 1 & 2 & 2A & 724.66 & 0.147 & Cacat \\
2 & 2 & 2B & 804.22 & 0.148 & Cacat \\
3 & 2 & 2C & 809.79 & 0.151 & Cacat \\
\multicolumn{2}{c}{ Rata-rata } & 779.56 & 0.148 & \\
\hline
\end{tabular}

4. Hasil pengujian impak jatuh bebas spesimen 3 ketinggian 1.5 meter Beban $10 \mathrm{Kg}$
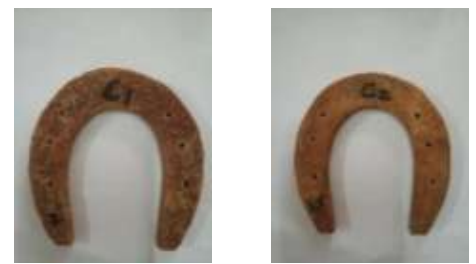

(a)

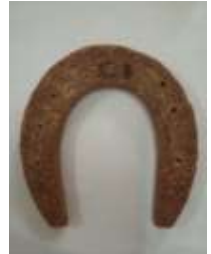

Gambar 10. Spesimen 3 (a) Sebelum diuji (b) Setelah diuji

Spesimen uji dijatuhkan dari ketinggian 1,5 meter bersama beban $10 \mathrm{~kg}$, tidak mengalami kerusakan. Nilai tegangan tertinggi dari dampak yang dihasilkan oleh gaya tertinggi terdapat pada spesimen 3A dengan nilai gaya 721,28 N. Detil nilainya dapat kita lihat pada gambar dan tabel berikut ini. 


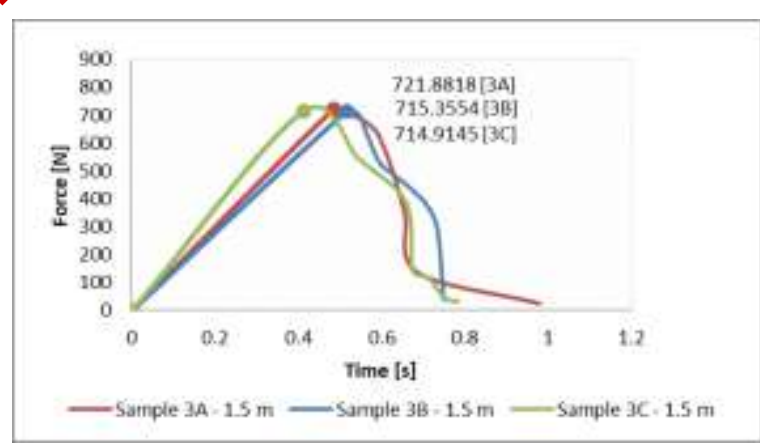

(a)

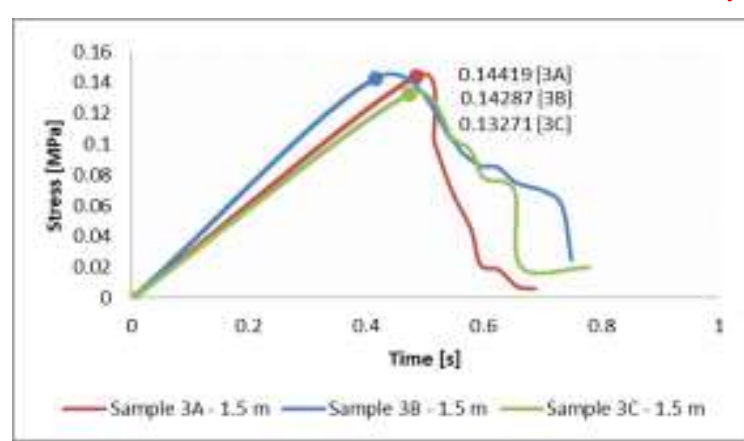

(b)

Gambar 11. Grafik Spesimen 3 (a) Gaya Vs Waktu (b) Tegangan Vs Waktu

Gaya terbesar terdapat pada spesimen 3A sebesar 721,8N dan tegangannya 0,14 MPa.

Detilnya dapat kita lihat pada tabel 5 dibawah ini.

Tabel 5. Data uji impak sampel 3 sepatu kuda ketinggian 2 meter

\begin{tabular}{cccccc}
\hline No & $\begin{array}{c}\text { Ketinggian } \\
(\mathrm{m})\end{array}$ & Spesimen & $\begin{array}{c}\text { Gaya Maksimum } \\
(\mathrm{N})\end{array}$ & $\begin{array}{c}\text { Tegangan Maksimum } \\
(\mathrm{MPa})\end{array}$ & Kondisi \\
\hline 1 & 1.5 & 3A & 721.8818 & 0.14419 & Cacat \\
2 & 1.5 & 3B & 715.3554 & 0.142869 & Cacat \\
3 & 1.5 & 3C & 714.9145 & 0.132710 & Cacat \\
\hline \multicolumn{7}{c}{ Rata-rata } & 717.3839 & 0.139923 & \\
\hline
\end{tabular}

5. Hasil pengujian impak jatuh bebas spesimen 4 ketinggian 1 meter Beban $10 \mathrm{Kg}$
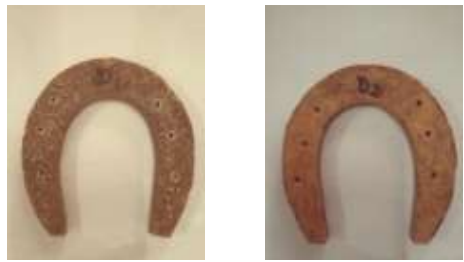

(a)

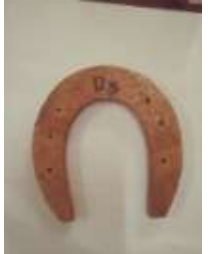

Gambar 12. Spesimen 4 (a) Sebelum diuji (b) Setelah diuji

Spesimen 4, dilakukan pengujian pada ketinggian $1 \mathrm{~m}$ dengan beban 10 kgkondisinya tidak mengalami retak/ rusak. Data hasil gaya dan tegangan diperlihatkan pada gambar grafik berikut ini.

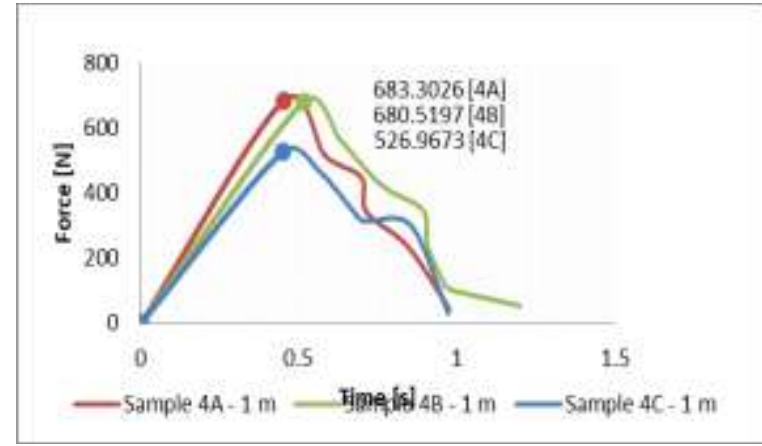

(a)

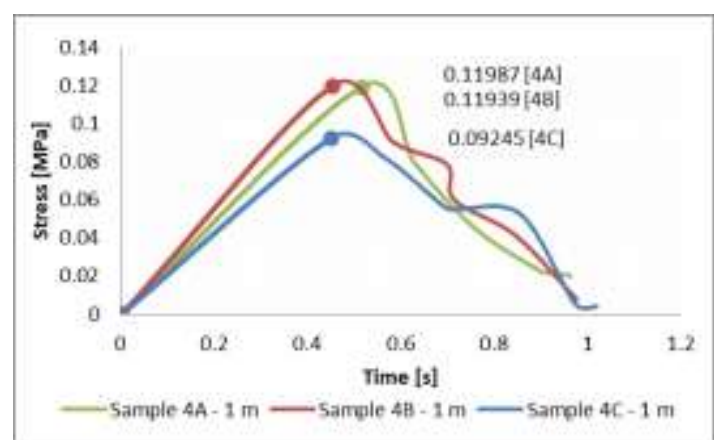

(b)

Gambar 13. Grafik Spesimen 4 (a) Gaya Vs Waktu (b) Tegangan Vs Waktu

Copyright $^{\circledR} 2020$ Jurnal Rekayasa Material, Manufaktur dan Energi. This is an open acces article under the CC-BY-SA lisence (https://creativecommons.org/licenses/by-sa/4.0/). 
Spesimen 4A mendapatkan nilai gaya maksimum dengan tegangan 0.19MPa.

Tabel 6. Data uji impak spesimen 4 sepatu kuda ketinggian 1 meter

\begin{tabular}{cccccc}
\hline No & $\begin{array}{c}\text { Ketinggian } \\
(\mathrm{m})\end{array}$ & Spesimen & $\begin{array}{c}\text { Gaya Maksimum } \\
(\mathrm{N})\end{array}$ & $\begin{array}{c}\text { Tegangan Maksimum } \\
(\mathrm{MPa})\end{array}$ & Kondisi \\
\hline 1 & 1 & 4A & 683.30 & 0.1199 & Cacat \\
2 & 1 & 4B & 680.52 & 0.1194 & Cacat \\
3 & 1 & 4C & 526.97 & 0.0925 & Cacat \\
\hline \multicolumn{7}{c}{ Rata-rata } & 630.26 & 0.111 & \\
\hline
\end{tabular}

6. Hasil pengujian impak jatuh bebas spesimen 5 ketinggian 0.5 meter Beban $10 \mathrm{Kg}$

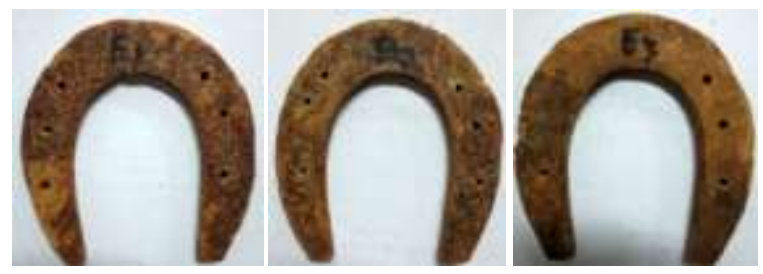

Gambar 14. Sampel 5 setelah diuji

Hasil pengujian spesimen 5 sama sekali tidak ada kerusakan. Nilai gaya dan tegangannya diperlihatkan pada gambar berikut.

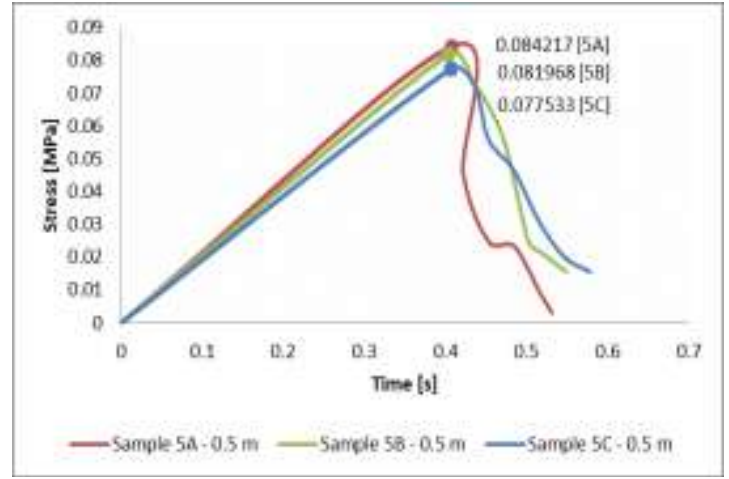

(a)

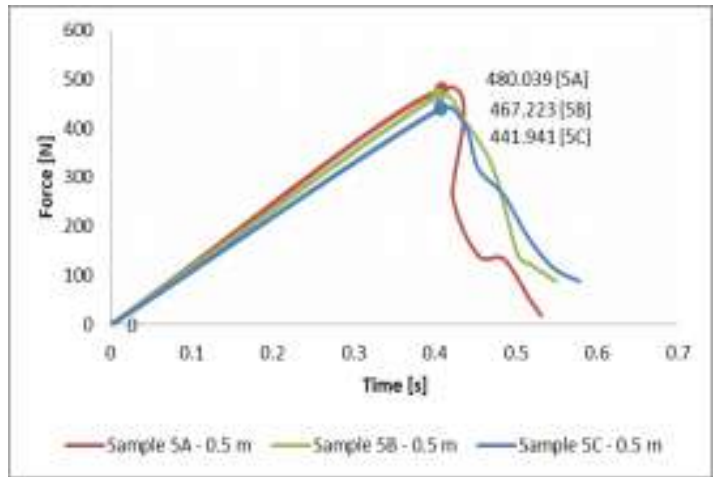

(b)

Gambar 15. Grafik Spesimen 5 (a) Gaya Vs Waktu (b) Tegangan Vs Waktu

Data menunjukkan nilai gaya 5A sebesar 480,039 $\mathrm{N}$ dan tegangan sebesar $0.084 \mathrm{MPa}$.

Tabel 7. Data uji impak spesimen 5 sepatu kuda ketinggian 0,5 meter

\begin{tabular}{cccccc}
\hline No & $\begin{array}{c}\text { Ketinggian } \\
(\mathrm{m})\end{array}$ & Spesimen & $\begin{array}{c}\text { Gaya Maksimum } \\
(\mathrm{N})\end{array}$ & $\begin{array}{c}\text { Tegangan Maksimum } \\
(\mathrm{MPa})\end{array}$ & Kondisi \\
\hline 1 & 1.5 & $5 \mathrm{~A}$ & 480.039 & 0.084 & Cacat \\
2 & 1.5 & 5B & 467.223 & 0.082 & Cacat \\
3 & 1.5 & $5 \mathrm{C}$ & 441.940 & 0.077 & Cacat \\
\hline \multicolumn{7}{c}{ Rata-rata } & 463.067 & 0.081 & \\
\hline
\end{tabular}

7. Hasil pengujian impak jatuh bebas spesimen 6 ketinggian 3 meter Beban $12.5 \mathrm{Kg}$

Spesimen uji 6, dipasang pada anvil ketinggian 3 meter dengan beban $12.5 \mathrm{~kg}$, hasilnya adalah patah dan retak, bebrbeda dengan beban yang $10 \mathrm{~kg}$ hasilnya sama sekali tidak pecah. 


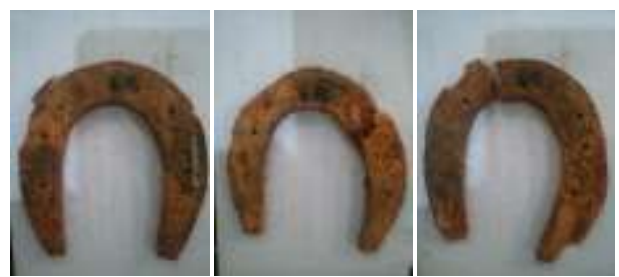

Gambar 16. Spesimen 6 setelah diuji

Berikut ini grafik data hasil gaya dan tegangan pada spesimen 6 pada gambar berikut ini

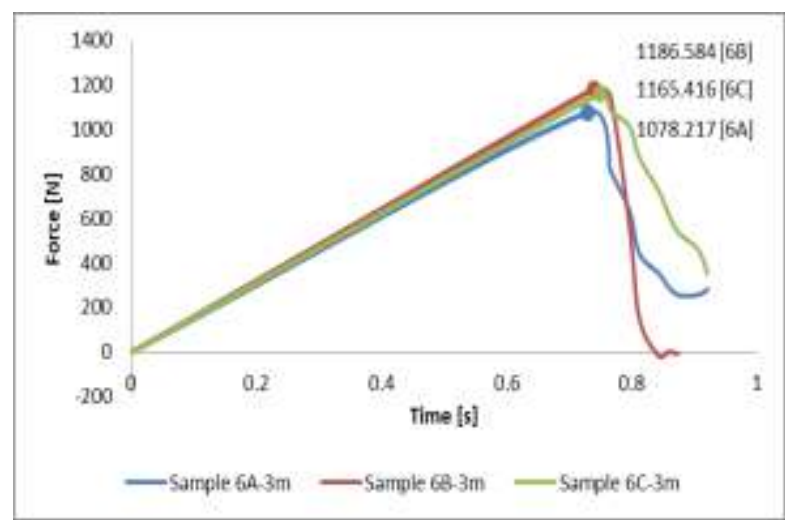

(a)

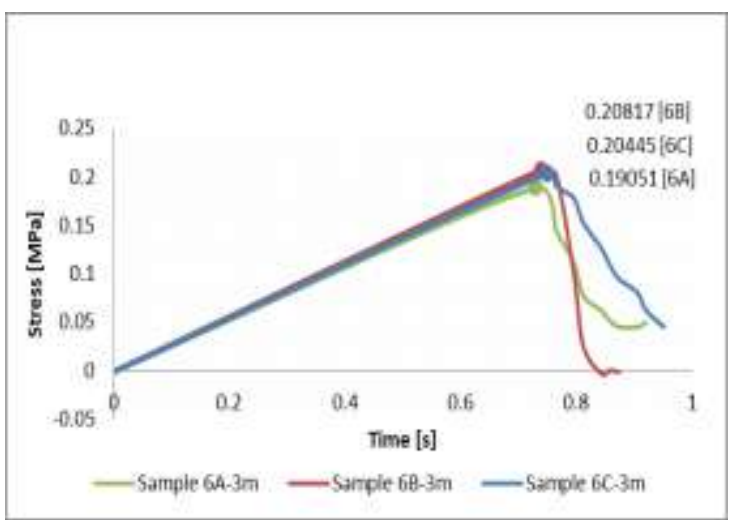

(b)

Gambar 17. Grafik Spesimen 6 (a) Gaya Vs Waktu (b) Tegangan Vs Waktu

Nilai gaya dan tegangan maksimum terdapat pada spesimen $6 \mathrm{C}$ sebesar $1186.54 \mathrm{~N}$ dan 0,19 Mpa.

Tabel 8. Data uji impak spesimen 6 sepatu kuda ketinggian 3 meter Beban $12.5 \mathrm{Kg}$

\begin{tabular}{cccccc}
\hline No & $\begin{array}{c}\text { Ketinggian } \\
(\mathrm{m})\end{array}$ & Spesimen & $\begin{array}{c}\text { Gaya Maksimum } \\
(\mathrm{N})\end{array}$ & $\begin{array}{c}\text { Tegangan Maksimum } \\
(\mathrm{MPa})\end{array}$ & Kondisi \\
\hline 1 & 3 & 6A & 1078.217 & 0.19051 & Retak \\
2 & 3 & 6B & 1165.416 & 0.20817 & Patah \\
3 & 3 & 6C & 1186.584 & 0.20445 & Patah \\
\hline \multicolumn{7}{c}{ Rata-rata } & 1143.406 & 0.20143 & \\
\hline
\end{tabular}

8. Hasil pengujian impak jatuh bebas spesimen 7 ketinggian 2.5 meter Beban $12.5 \mathrm{Kg}$.

Hasil pengujian impak jatuh bebas pada spesimen 7 sepatu kuda bahan polymeric foam dengan penguat fiberglass jarak ketinggian beban 2.5 meter dengan beban impaktor $12.5 \mathrm{~kg}$ diperlihatkan pada gambar berikut ini
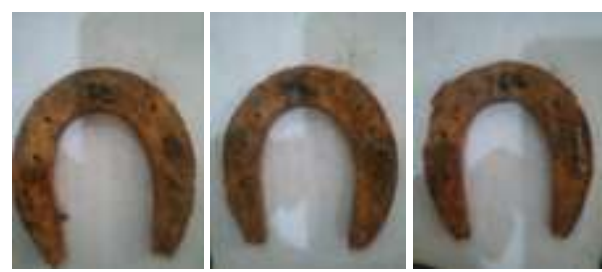

Gambar 18. Spesimen7 setelah diuji

Copyright $^{\circledR} 2020$ Jurnal Rekayasa Material, Manufaktur dan Energi. This is an open acces article under the CC-BY-SA lisence (https://creativecommons.org/licenses/by-sa/4.0/). 


\section{Jurnal Rekayasa Material, Manufaktur dan Energi}

Spesimen 7 setelah dilakukan pengujian pada ketinggian 2,5 $\mathrm{m}$ dan beban 12,5 kg kondisinya pecah dan retak. Hasil gaya dan tegangan diperlihatkan pada grafik gambar dibawah ini.

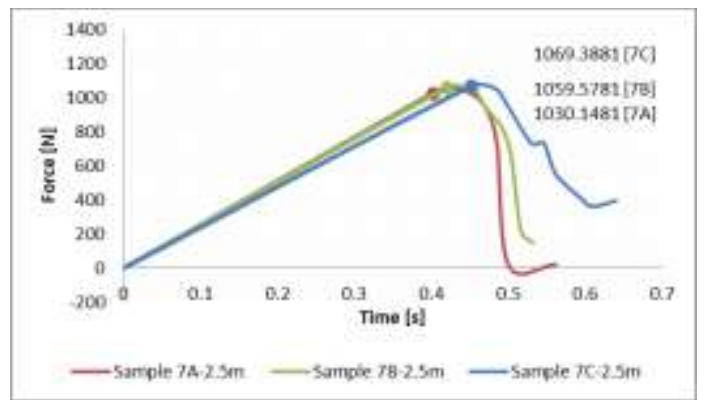

(a)

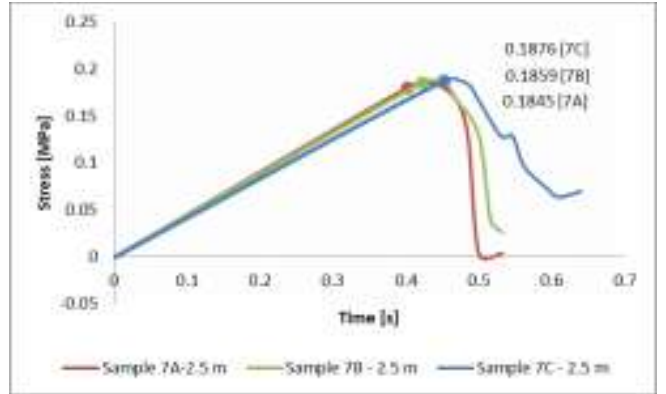

(b)

Gambar 19. Grafik Spesimen 7 (a) Gaya Vs Waktu (b) Tegangan Vs Waktu

Gambar 19 menunjukkan nilai gaya dan tegangan makimum adalah: 7C dengan gaya maksimim sebesar $1069 \mathrm{~N}$ dan tegangannya sebesar 0,185 MPa.

Tabel 9. Data uji impak spesimen 7 sepatu kuda ketinggian 2,5 meter Beban $12.5 \mathrm{Kg}$

\begin{tabular}{cccccc}
\hline No & $\begin{array}{c}\text { Ketinggian } \\
(\mathrm{m})\end{array}$ & Spesimen & $\begin{array}{c}\text { Gaya Maksimum } \\
(\mathrm{N})\end{array}$ & $\begin{array}{c}\text { Tegangan Maksimum } \\
(\mathrm{MPa})\end{array}$ & Kondisi \\
\hline 1 & 2.5 & $7 \mathrm{~A}$ & 1030.1481 & 0.18451 & Retak \\
2 & 2.5 & $7 \mathrm{~B}$ & 1059.5781 & 0.18590 & Retak \\
3 & 2.5 & $7 \mathrm{C}$ & 1069.3881 & 0.18760 & Retak \\
\hline \multicolumn{7}{c}{ Rata-rata } & 1053.0381 & 0.186003 & \\
\hline
\end{tabular}

9. Kumpulan Data Hasil Pengujian Impak Jatuh Bebas Beban $10 \mathrm{~kg}$

Rangkuman hasil keseluruhan gaya yang didapat dari pengujian impak jatuh bebas terhadap lima spesimen sepatu kuda 1, 2, 3, 4 dan 5, dengan beban impaktor $10 \mathrm{~kg}$ dapat dilihat pada gambar 4.15 yang juga merupakan grafik gaya maksimum rata-rata.

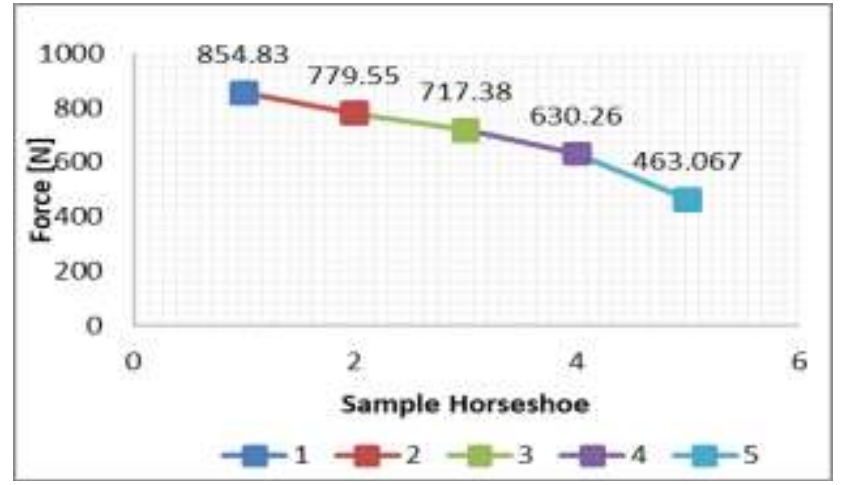

Gambar 20. Rangkuman data gaya terhadap spesimen sepatu kuda beban $10 \mathrm{~kg}$

Grafik diatas pada spesimen 1 sepatu kuda dari jarak ketinggian impak $2.5 \mathrm{~m}$ terhadap beban $10 \mathrm{~kg}$ menunjukkan angka gaya maksimum rata rata spesimen 1 sebesar $854,83 \mathrm{~N}$. Detil hasil keseluruhan tegangan maksimum rata-rata spesimen uji sepatu kuda 1, 2, 3, 4 dan 5 dengan beban impaktor $10 \mathrm{~kg}$ diperlihatkan pada gambar berikut. 


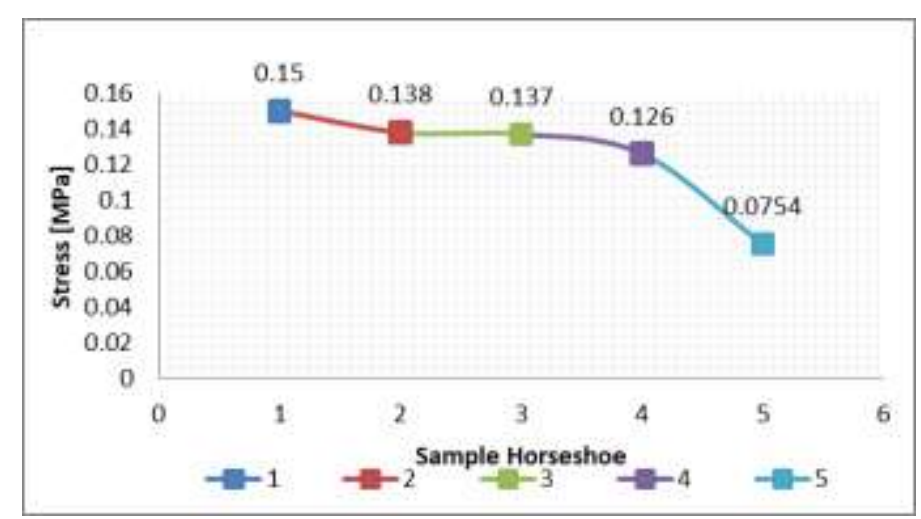

Gambar 21. Rangkuman data Tegangan terhadap spesimen sepatu kuda beban $10 \mathrm{~kg}$

Grafik diatas pada spesimen 1 sepatu kuda dari jarak ketinggian impak 2.5 m terhadap beban $10 \mathrm{~kg}$ menunjukkan angka tegangan maksimum rata rata spesimen 1 sebesar 0,15 MPa.

10. Kumpulan Data Hasil Pengujian Impak Jatuh Bebas dengan Beban $12.5 \mathrm{~kg}$ Rangkuman hasil keseluruhan gaya yang didapat dari pengujian impak jatuh bebas spesimen uji 6 dan 7 diperlihatkan pada grafik gambar berikut ini

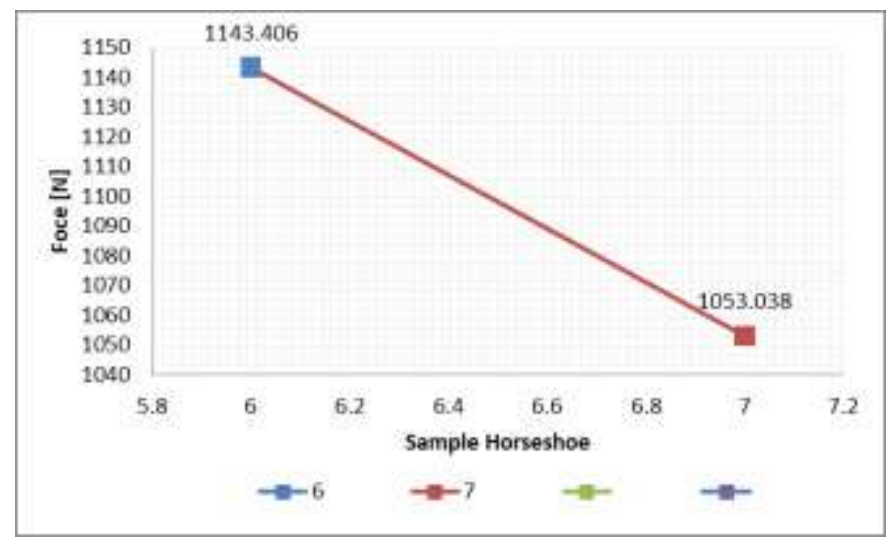

Gambar 22. Rangkuman data gaya terhadap sampel sepatu kuda beban $12.5 \mathrm{~kg}$.

Grafik diatas pada spesimen 6 dan 7 sepatu kuda dari jarak ketinggian impak 3 dan 2,5 m terhadap beban 12,5 kg menunjukkan angka gaya maksimum rata rata spesimen 6 sebesar $1143,41 \mathrm{~N}$. Nilai tegangan maksimum rata-rata yang dihasilkan dari uji impak jatuh bebas terdapat pada spesimen 6 sebesar 0,20 MPa. Detil hasil keseluruhan tegangan maksimum ratarata spesimen uji sepatu kuda 6 dan 7 dengan beban impaktor 12,5 $\mathrm{kg}$ diperlihatkan pada gambar 4.18. 


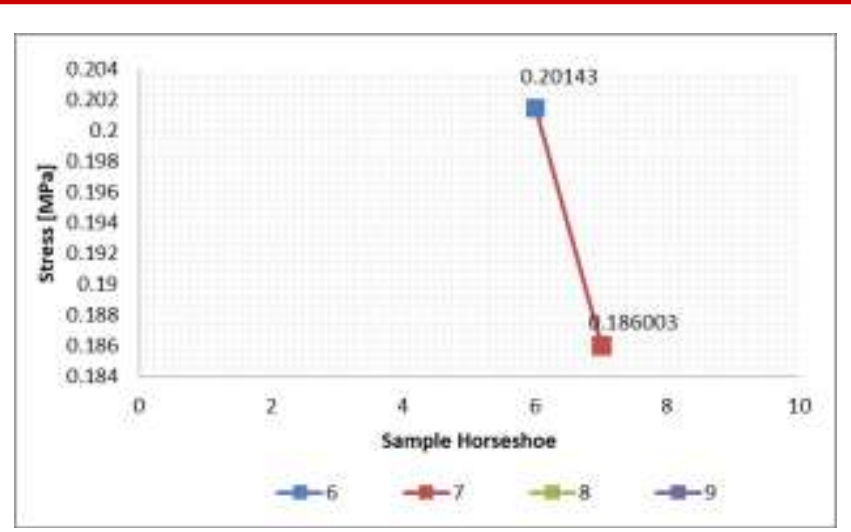

Gambar 23. Rangkuman data tegangan terhadap spesimen sepatu kuda beban $12,5 \mathrm{~kg}$

11. Perhitungan Gaya dan Tegangan sepatu kuda saat berjalan

Berikut perhitungan pengujian impak jatuh bebas secara langsung pada sepatu kuda. Beban maksimum yang dialami dinding kuku kuda oleh kuku kuda secara adalah 2.4 kali berat kuda. Gaya tersebut secara rinci seperti terlihat pada persamaan:

$$
\mathrm{F}=\mathrm{m} \cdot \mathrm{g} \cdot 2,4(\mathrm{kN})
$$

Massa diasumsikan Sesuai dengan survey yang dilakukan di kota Berastagi, ditemukan massa kuda mencapai $100 \mathrm{~kg}, 200 \mathrm{~kg}$ hingga $300 \mathrm{~kg}$, dimana kuda menerima beban kaki kuda bagian depan lebih besar 55\% hingga 70\%, maka untuk dilakukan perhitungan digunakan massa kuda yang terbesar yaitu $300 \mathrm{~kg}$, kaki bagian depan menerima beban sebesar $60 \%$ dari keseluruhan berat kuda, maka satu kaki depan menerima 30\% dari massanya yaitu $90 \mathrm{~kg}$. Khusus untuk kuda dengan massa $100 \mathrm{~kg}$ dengan beban kaki belakang $40 \%$, massa nya menjadi $20 \mathrm{~kg}$ persamaannya menjadi:

$$
\begin{aligned}
& \mathrm{F}=20 \mathrm{~kg} \times 9.81 \mathrm{~m} / \mathrm{s}^{2} \times 2.4 \\
& \mathrm{~F}=470.88 \mathrm{~N} \\
& \mathrm{~F}=0.471 \mathrm{kN}
\end{aligned}
$$

Luas area kontak permukaan sepatu kuda terhadap anvill adalah luas area sepatu kuda sebesar: $\mathrm{A}=5700 \mathrm{~mm}$. Rumus tegangan yang terjadi pada sepatu kuda terlihat pada persamaan (2) berikut.

$$
\sigma=\frac{\mathrm{F}}{\mathrm{Ao}}
$$

Tegangan yang terjadi untuk masssa kuda $100 \mathrm{~kg}$ untuk kaki depan adalah:

$$
\begin{aligned}
& \sigma=\frac{706.32}{5700} \frac{\mathrm{N}}{\mathrm{mm}^{2}} \\
& \sigma=0.12 \mathrm{MPa}
\end{aligned}
$$

12. Energi Impak

$$
\mathrm{E}_{\mathrm{i}}=\mathrm{m} \times \mathrm{h}
$$

Diketahui: $\mathrm{m}=12.5 \mathrm{~kg}, \mathrm{~h}=3$ meter dan $\mathrm{g}=9.81 \mathrm{~m} / \mathrm{s}^{2}$ 


$$
\begin{aligned}
& \mathrm{Ei}=12,5 \times 9.81 \times 3 \\
& \mathrm{Ei}=367,875 \text { Joule }
\end{aligned}
$$

13. Energi Impak Eksperimenta :

$$
1 \mathrm{E}_{\mathrm{Ie}}=\mathrm{F} \cdot \mathrm{h}
$$

Diketahui : $\mathrm{F}$ untuk spesimen 6A $=1078.217 \mathrm{~N}$ dan $\mathrm{h}=3 \mathrm{~m}$

$$
\begin{aligned}
& \text { Eie }=1078,217 \times 3 \\
& \text { Eie }=3234,651 \text { Joule }
\end{aligned}
$$

14. Energi yang diserap

$$
\begin{aligned}
& E_{S}=E_{I e}- E_{I} \\
& E s=3234,651-367,875 \\
& \text { Es }=2866,776 \text { Joule }
\end{aligned}
$$

\section{KESIMPULAN}

Kesimpulan yang dapat diambil dari analisa sepatu kuda bahan komposit polymeric foam diperkuat fiberglass pada penelitian ini adalah:

1. Spesimen 1 sepatu kuda pada ketinggian 2.5 meter dan berat impaktor $10 \mathrm{~kg}$. Nilai gaya maksimum rata-rata spesimen 1 sebesar $854.84 \mathrm{~N}$ dan tegangan maksimum rata-rata $0.15 \mathrm{MPa}$.

2. Spesimen 2 sepatu kuda pada ketinggian 2 meter dan berat impaktor $10 \mathrm{~kg}$. Nilai Gaya maksimum rata-rata spesimen 2 sebesar $779.56 \mathrm{~N}$ dan tegangan maksimum rata rata 0.149 MPa.

3. Spesimen 3 sepatu kuda ketinggian 1.5 meter dan berat impaktor $10 \mathrm{~kg}$. Nilai gaya maksimum rata-rata spesimen 3 sebesar $717.38 \mathrm{~N}$ dan tegangan maksimum rata-rata 0.139 MPa.

4. Spesimen 4 sepatu kuda pada ketinggian 1 meter dan berat impaktor $10 \mathrm{~kg}$. Nilai gaya maksimum rata-rata spesimen 4 sebesar $630.26 \mathrm{~N}$ dan tegangan maksimum rata-rata 0.121 MPa.

5. Spesimen 5 sepatu kuda pada ketinggian 0.5 meter dan berat impaktor $10 \mathrm{~kg}$. Nilai gaya maksimum rata-rata spesimen 5 sebesar $429.7343 \mathrm{~N}$ dan tegangan maksimum rata-rata $0.072874 \mathrm{MPa}$.

6. Spesimen 6 sepatu kuda pada ketinggian 3 meter dan berat impaktor $12.5 \mathrm{~kg}$. Nilai gaya maksimum rata-rata spesimen 6 sebesar $1143.406 \mathrm{~N}$ dan tegangan maksimum rata-rata $0.20143 \mathrm{MPa}$.

7. Spesimen7 sepatu kuda ketinggian 2.5 meter dan berat impaktor $12.5 \mathrm{~kg}$. Nilai gaya maksimum rata-rata spesimen 7 sebesar $1053.0381 \mathrm{~N}$ dan tegangan maksimum rata-rata $0.186003 \mathrm{MPa}$.

\section{DAFTAR USTAKA}

[1] Ongkowidjojo C, 2014, Implementasi Konsep Kuda Sandel Pada Interior Bangunan Utama Arena Pacuan Kuda Pasuruan. Program Studi Desain Interior. Jurnal Intra Vol.2 No. 2, 508-514. Universitas Kristen Petra Jl. Siwalankerto 121-131, Surabaya.

[2] Martín L,A, 2014, Alternative Materials For The Horseshoe, unpublished Bachelor Degree Project in Mechanical Engineering C-Level 22.5 ECTS Spring term, pp 
[3] Mawardi 2019, Bustami Syam, Basuki Wirjosentono, Donny Surya Dharma "Manufacture of Polymeric Foam and Polyurethane Composites With Fiberglass Boosters" SEMIRATAICST 2018 https://ocs.usu.ac.id/semirataicst/SemirataICST/index.

[4] Ismail, H, 2004, Komposit Polimer Diperkuat Pengisi dan Gentian Pendek Semula Jadi, Penerbit Universiti Sains Malaysia, Pulau Pinang.

[5] Raj, R. G., Kokta, B. V. Dan Daneault, 1990, "A Comparative Study on the Effect of Aging on Mechanical.

[6] American Iron \& Steel Institute, New York; SAE Standard J403f. Reprinted with permission.

[7] Martín L,A, 2014, Alternative Materials For The Horseshoe, unpublished Bachelor Degree Project in Mechanical Engineering C-Level 22.5 ECTS Spring term, pp 10.

[8] Mohammed M H, Dauda B 2014, Unsaturated Polyester Resin Reinforced With Chemically Modified Natural Fibre, IOSR Journal of Polymer and Textile Engineering (IOSR-JPTE) e-ISSN: 2348-019X, p-ISSN: 2348-0181, Volume 1, Issue 4 (Sep-Oct. 2014), PP 31-38.

[9] Rooney, J R. The Lame Horse. Neenah, WI. Meerdink (1998).

[10] Witte, T., Knill, K. \& Wilson, A., 2004. Determination of peak vertical ground reaction force from duty factor in the horse (Equus caballus). The Journal of Experimental Biology 207 pp.3639-3648.

[11] Sukardi. 2014."Studi Eksperimental Dan Analisa Respon Mekanik Helmet Sepeda Dari Bahan Komposit Busa Polimer Diperkuat Serat TKKS Akibat Beban Impak Jatuh Bebas" (SkripsiDepartemen Teknik Mesin USU) 